\title{
A case of renal cell carcinoma in a patient with situs inversus: Operative considerations and a review of the literature
}

\author{
Justin Oake, MD; Darrel Drachenberg, MD, FRCSC
}

Section of Urology, University of Manitoba, Winnipeg, MB, Canada

Cite as: Can Urol Assoc J 2017;11 (5):E233-6. http://dx.doi.org/10.5489/cuaj.4290

Published online May 9, 2017

\section{Abstract}

Situs inversus, an uncommon mirror-image reversal of the major visceral and thoracic organs, is seldom of medical significance. However, the recognition of their unique anatomy is extremely important for those requiring surgical intervention. There are very few reported cases of renal cell carcinoma (RCC) developing in people with situs inversus. To our knowledge, this is the first reported case in Canada. A review of the literature only identified nine published cases worldwide. Here, we review and summarize pertinent information, including patient age and sex, size and location of tumour, method of surgery, and pathology. Our case, a 65-yearold male, presented with left flank pain and gross hematuria. He was diagnosed with left renal cancer as well as tumour thrombus extending into the left renal veins and inferior vena cava (IVC), clinical T3aNOMO. An abdomen and pelvis computed tomography (CT) scan showed a left-to-right reversal of his organs, a mirrorimage, and situs inversus was diagnosed. A left radical nephrectomy with left renal vein and IVC tumour thrombectomy through a left open midline incision was performed.

\section{Introduction}

Situs inversus, the complete mirror-image reversal of the organs, is very rare, with a prevalence of $1 / 20000 .{ }^{1}$ Renal anomalies, including dysplasia, agenesis, polycystic kidney, hypoplasia, ectopia, and horseshoe kidney, have been reported in situs inversus. It is also associated with cardiac and pulmonary anomalies. ${ }^{2-6}$ Kartagener syndrome (immotility of bronchial cilia, bronchiectasis, chronic sinusitis, male infertility) coexists in $20-25 \%$ of situs inversus cases. ${ }^{6}$ There is no known evidence that situs inversus increases the risk of malignancy. ${ }^{3}$ Although Aristotle first described situs inversus in animals, it was not recognized in humans until 1600 by Fabricus. Subsequently, in 1897, Vehemeyer was the first to discover this anomaly by roentgen-ray examination and since then, cases have been recognized with increasing frequency. ${ }^{7}$ We present the first case reported in Canada of renal cell carcinoma (RCC) in a patient with situs inversus.

\section{Case report}

A 65-year-old male was initially referred in 2015 with a presentation of left flank pain and gross hematuria. Computed tomography (CT) scan of the abdomen and pelvis described a hypervascular enhancing mass $(9.1 \times 7.2 \times 10 \mathrm{~cm})$ within the left kidney in keeping with a RCC and invasion of the mass into the left renal veins. Also of importance, they noted a mirror-image of the organs with left-to-right disposition, resulting in diagnosis of situs inversus (Fig. 1). A chest X-ray revealed dextrocardia (Fig. 2). In order to further delineate the level of the thrombus, we arranged for an urgent renal magnetic resonance imaging (MRI) scan. The gadoliniumenhanced MRI angiography demonstrated the patient's unique anatomy, which included the inferior vena cava (IVC) being left of the aorta; additionally, the patient had two renal veins and there were a number of extrarenal arteries travelling both anterior and posterior to the IVC (Fig. 3). Left RCC was noted extending into both left renal veins (Fig. 4). The tumour extended into the more inferior left renal vein and extended into the IVC, approximately $3 \mathrm{~mm}$ beyond its junction with the cava. The mass also extended into the more superior of the two left renal veins, where it terminated approximately $3 \mathrm{~mm}$ before it reached the IVC. There was no evidence of intra-abdominal metastatic disease. Based on several radiological examinations, we clinically diagnosed this patient as having T3aNOMO.

Taking into account the patient's distinctive anatomy, as well as his renal vein and IVC tumour thrombus, the patient elected to undergo a left, open, midline radical nephrectomy with a renal vein and IVC tumour thrombectomy. In addition, the patient's CT scans noted a significant burden of cholelithiasis; therefore, we also arranged for an open cholecystectomy to be completed. In the supine position, a midline incision was made subxiphoid. Once we entered 

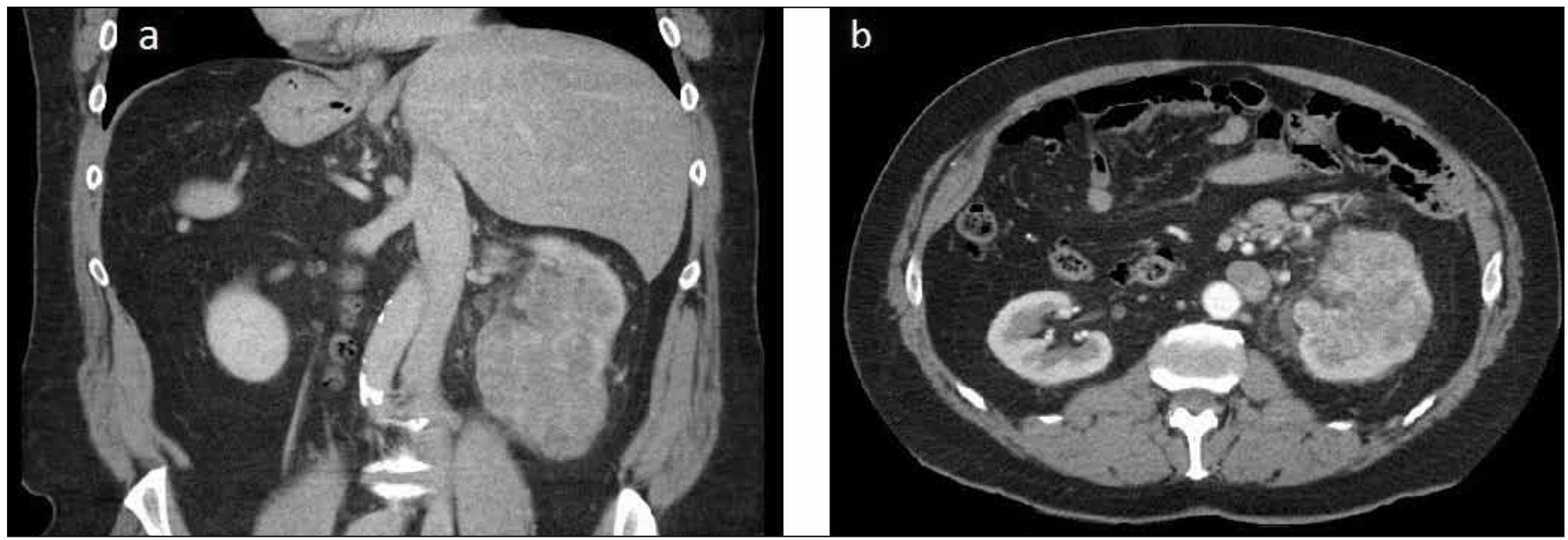

Fig. 1. A computed tomography scan showing the intra-abdominal organs positioned (a) inversely in a mirror-image; and (b) a tumour in the left kidney.

the peritoneum, we found an extremely large renal vein thrombus into the IVC from the lower pole renal vein. The more cephalad renal vein was identified and it also had thombus infiltrating into the IVC. The lateral and posterior attachments of the left kidney were dissected. Both renal veins had the thrombus excluded from circulation via side biting vascular clamping and were oversewn after division with 4-0 vascular Prolene baseball suture. The specimen was removed through the midline incision and followed by an open cholecystectomy. The patient tolerated the procedure well and was discharged home postoperative day 4 . Pathological examination from the left renal mass revealed clear-cell RCC of Fuhrman grade 3 and pT3aNOMO. The patient has done well postoperatively and has not encountered any recurrence of disease.

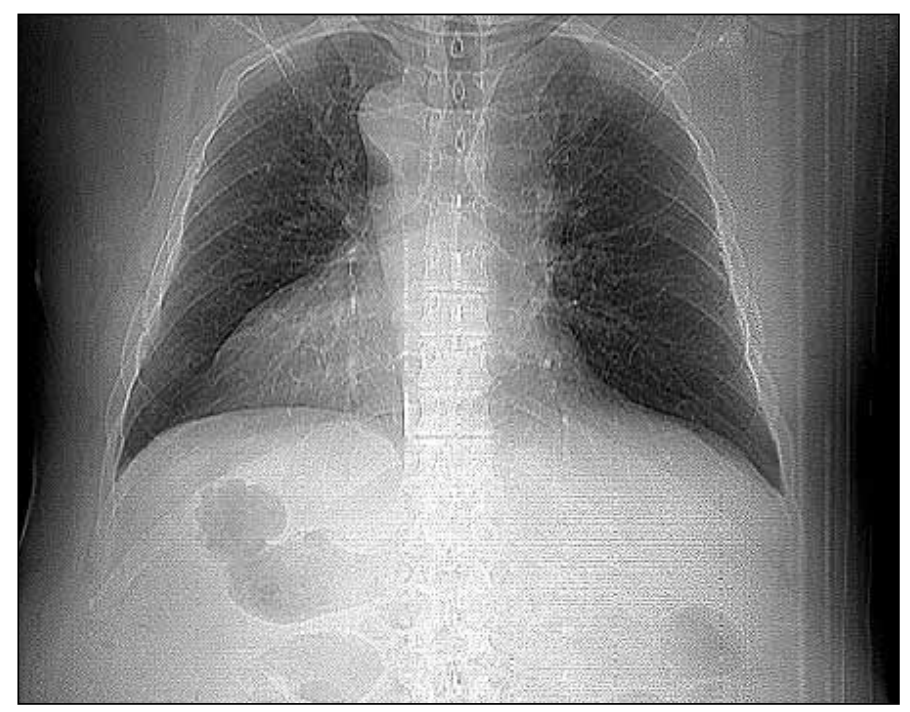

\section{Discussion}

There are very few documented cases in the literature surrounding RCC in patients with situs inversus. A literature search revealed nine published articles, seven in English, one in Spanish, and one in Japanese (Table 1). The Japanese and Spanish articles were translated in English with the help of Google translator on September 9, 2016. The first reported case was in $1987 .{ }^{8}$ The articles' types included nine case reports. Eight of the nine cases were male patients. The majority of patients with situs inversus had left-sided RCC $(56 \%)$ and the most common surgical intervention was an open radical nephrectomy (67\%). The geographic distribution was: three from Japan, three from the U.S., one from Spain, one from India, and one from Zambia.

In RCC patients with situs inversus, several suitable surgical methods have been discussed, including open and laparoscopic techniques. ${ }^{3,9,10}$ Regardless of the surgical intervention, the majority of reports emphasized technical difficulty because of disorientation due to the reversed position of the anatomy. ${ }^{11-13}$ Given the involvement of tumour thrombus invading into the IVC from two renal veins, we felt an open midline incision enabled an easier approach and minimized the risk of complications related to adjacent abdominal organs. Recently, Terakawa et al sought to reduce these technical difficulties by reporting the first successful completion of a laparoscopic radical nephrectomy carried out on a situs inversus patient with RCC using a retroperitoneal approach. ${ }^{11}$ They felt this approach prevented the transposed intraperitoneal organs from coming into the surgeon's field of vision. This approach was unfortunately not possible in our case of T3 disease; however, the appearance of transposed organs and surgical field of view does provide significant complexity.

Fig. 2. Chest X-ray showing dextrocardia. 


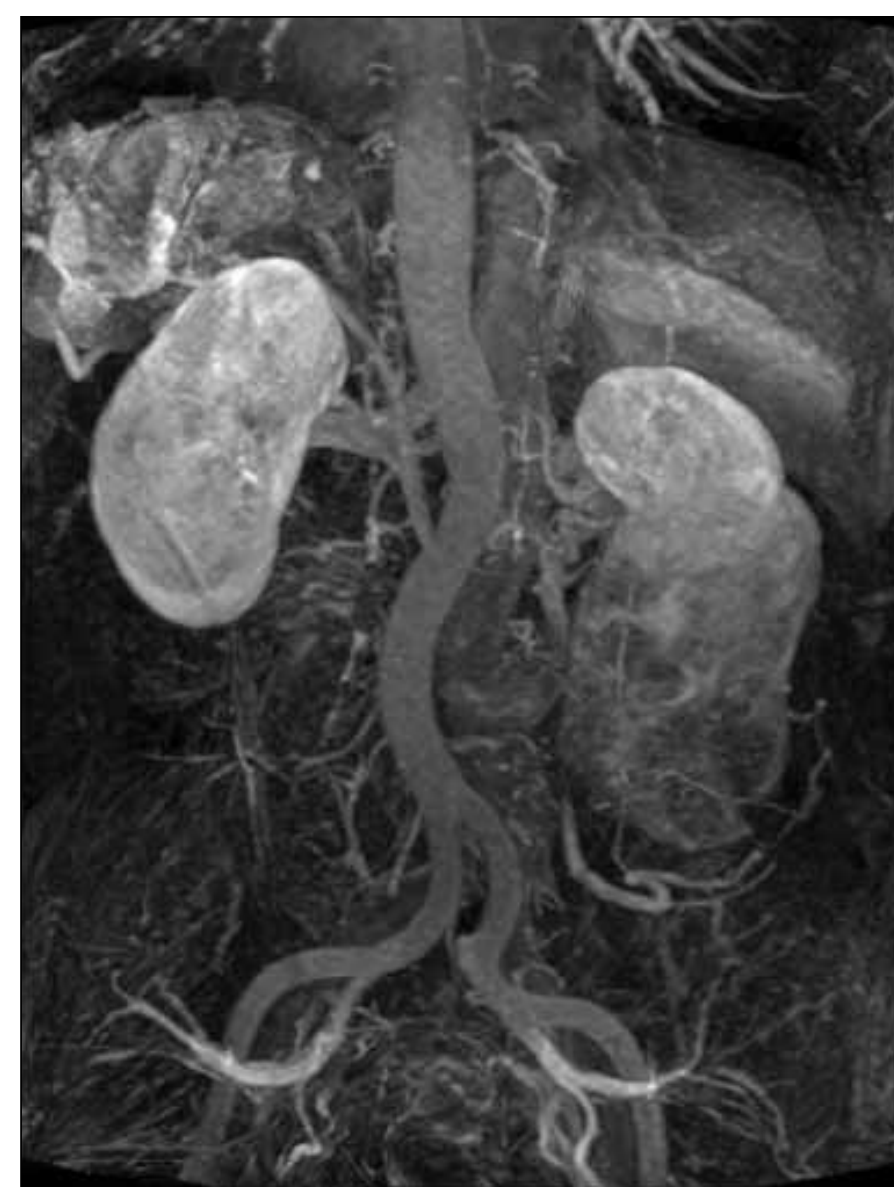

Fig. 3. A gadolinium-enhanced renal magnetic resonance image angiography demonstrating situs inversus and a left renal mass.

\section{Conclusion}

While RCC is the sixth and eleventh most common cancer diagnosed in men and women, respectively, ${ }^{14}$ concomitant RCC with situs inversus is incredibly rare. Only nine cases have been reported. This case and review of the literature also highlights the importance of careful preoperative evaluation. Furthermore, surgeons must recognize the inverseimage anatomy and modify their approach accordingly.

Competing interests: The authors report no competing personal or financial interests.

This paper has been peer-reviewed.

\section{References}

1. Levin M. The embryonic origins of left-right asymmetry. Crit Rev Oral Biol Med 2004;15:197-206. https://doi.org/10.1177/154411130401500403

2. Treiger BF, Khazan R, Goldman $S M$, et al. Renal cell carcinoma with situs inversus totalis. Urology 1993;41:455-7. https://doi.org/10.1016/0090-4295(93)90507-7

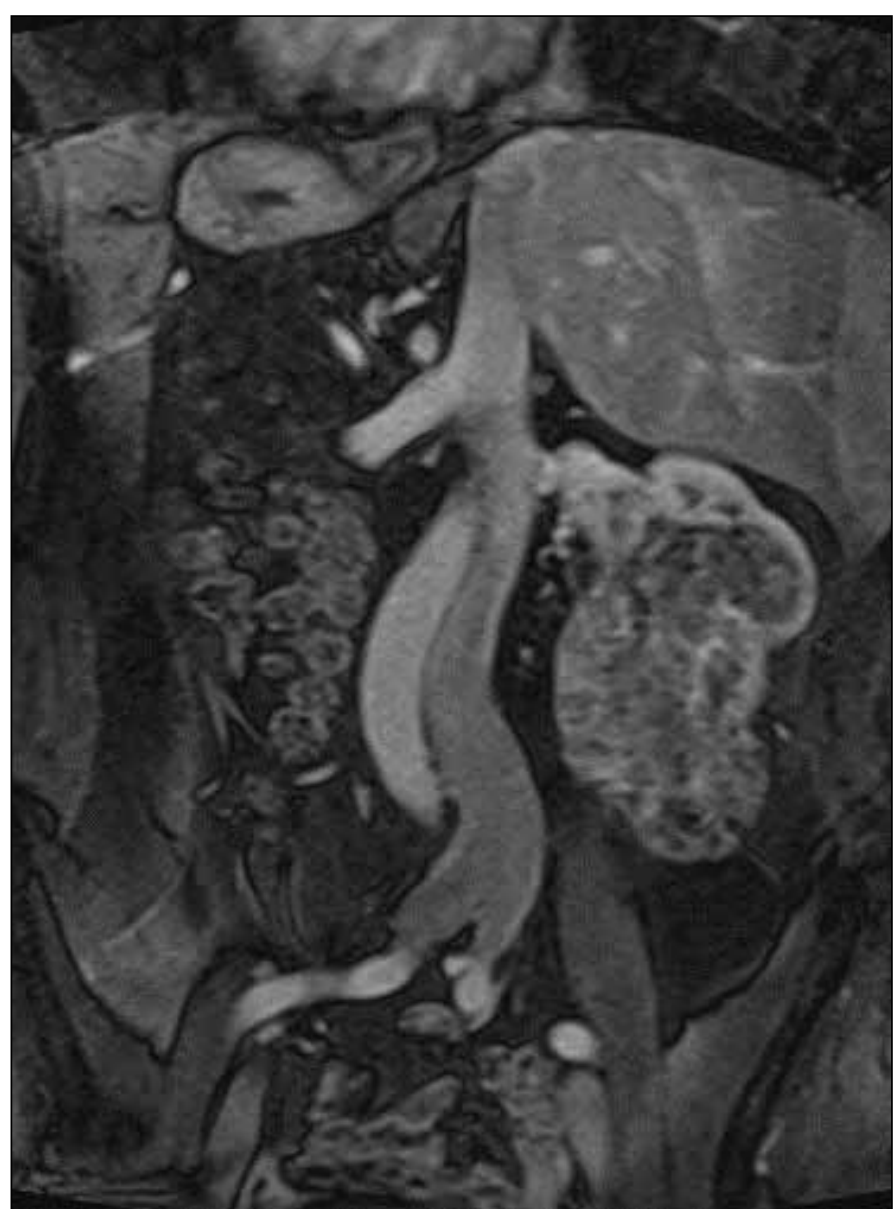

Fig. 4. A gadolinium-enhanced renal magnetic resonance image demonstrating renal cell carcinoma tumour thrombus extending into both left renal veins.

3. Adler HL, Lerner SP. Renal cell carcinoma and situs inversus viscerum. J Urol 1998;160:2141-2. https://doi.org/10.1016/S0022-5347(01)62262-6

4. Hoffmann D, Gunselman J, Chewaproug D, et al. Living-related donor nephrectomy in a patient with complete situs inversus. J Exp Clin Med 2010;2:305-6. https://doi.org/10.1016/i.jecm.2010.10.005

5. Patel RB, Gupta NR, Vasava NC, et al. Situs inversus totalis (SIT) with hepatocellular carcinoma (HCC): A rare case report and review of 12 other cases. Indian I Surg 2013;75:424-9. https://doi.org/10.1007/ s12262-012-0744-9

6. Wojick J, Grodzki T, Bielewicz M, et al. Lung cancer in situs inversus totalis (SIT)—literature review. Adv Med Sci 2013:58:1-8. https://doi.org/10.2478/v10039-012-0083-x

7. Blegen HM. Surgery in situs inversus. Ann Surg 1949;129:244-59. https://doi.org/10.1097/00000658194902000-00009

8. Bertini JE Jr, Boileau MA. Renal cell carcinoma in a patient with situs inversus totalis. J Surg Oncol 1987;34:29-31. https://doi.org/10.1002/iso.2930340109

9. Black PC, Porter JR, Charpentier KP, et al. Hand-assisted laparoscopic right-donor nephrectomy in a patient with situs inversus. Transplantation 2003;76:1530. https://doi.org/10.1097/01. TP.0000071361.98583.43

10. Makiyama K, Sakata R, Yamanaka H, et al. Laparoscopic nephroureterectomy in renal pelvic urothelial carcinoma with situs inversus totalis: Preoperative training using a patient-specific simulator. Urology 2012;80:1375-8. https://doi.org/10.1016/i.urology.2012.08.054

11. Terakawa T, Miyake H, Tanaka H, et al. Feasibility of a retroperitoneal approach as a surgical strategy for patients with situs inversus totalis: Presentation of a patient undergoing laparoscopic radical nephrectomy for renal cell carcinoma. Int Canc Conf J 2013;3:8-10. https://doi.org/10.1007/s13691-013-0105-y

12. Cimen HI, Atik YT, Adsan 0. Laparoscopic simple nephrectomy patient with situs inversus totalis and left renal hypoplasia: A case report. Can Urol Assoc J 2015;9:521-3. https://doi.org/10.5489/cuai.2824

13. Gonzalez-Heredia R, Garcia-Roca R, Benedetti E. Hand-assisted robotic right donor nephrectomy in patient with total situs inversus: A case report. Int I Surg Case Rep 2016;23:44-6. https://doi.org/10.1016/i. iiscr.2016.03.035 
Oake et al.

\section{Table 1. Publications on patients diagnosed with situs inversus and renal cell carcinoma}

\begin{tabular}{|c|c|c|c|c|c|c|c|c|c|c|}
\hline \multirow[b]{2}{*}{ No. } & \multirow[b]{2}{*}{ Case report } & \multirow[b]{2}{*}{$\begin{array}{c}\text { Country } \\
\text { (Language) }\end{array}$} & \multirow[b]{2}{*}{$\begin{array}{l}\text { Age/ } \\
\text { Sex }\end{array}$} & \multirow[b]{2}{*}{$\begin{array}{l}\text { Location } \\
\text { of RCC }\end{array}$} & \multirow[b]{2}{*}{$\begin{array}{l}\text { Tumour } \\
\text { size }\end{array}$} & \multirow[b]{2}{*}{$\begin{array}{c}\text { Open/lap } \\
\text { nephrectomy }\end{array}$} & \multirow[b]{2}{*}{$\begin{array}{c}\text { Radical/ partial } \\
\text { nephrectomy }\end{array}$} & \multicolumn{3}{|c|}{ Pathology } \\
\hline & & & & & & & & $\begin{array}{l}\text { Fuhrman } \\
\text { grade }\end{array}$ & Histology & pTNM \\
\hline 1 & $\begin{array}{l}\text { Bertini and } \\
\text { Boileau, } 1987^{8}\end{array}$ & $\begin{array}{c}\text { USA } \\
\text { (English) }\end{array}$ & $54 / F$ & $\mathrm{Rt}$ & - & Open & Radical & - & - & pT3aN1M0 \\
\hline 2 & $\begin{array}{c}\text { Treiger et al, } \\
1993^{2}\end{array}$ & $\begin{array}{c}\text { USA } \\
\text { (English) }\end{array}$ & $82 / \mathrm{M}$ & Lt & - & Open & Radical & - & - & pT(-)NOMO \\
\hline 3 & $\begin{array}{c}\text { Adler and Lerner, } \\
\qquad 1998^{3}\end{array}$ & $\begin{array}{c}\text { USA } \\
\text { (English) }\end{array}$ & $58 / \mathrm{M}$ & $\mathrm{Lt}$ & - & Open & Radical & 4 & - & pT3bN2M1 \\
\hline 4 & $\begin{array}{l}\text { Jimenez Verdejo } \\
\text { et al, 2000 }\end{array}$ & $\begin{array}{l}\text { Spain } \\
\text { (Spanish) }\end{array}$ & $43 / \mathrm{M}$ & Rt & - & Open & Radical & 2 & - & pT2NOMO \\
\hline 5 & $\begin{array}{c}\text { Jewell and Bowa, } \\
2001^{16}\end{array}$ & $\begin{array}{l}\text { Zambia } \\
\text { (English) }\end{array}$ & $43 / \mathrm{M}$ & $\mathrm{Lt}$ & - & Open & Radical & - & Clear-cell & $\mathrm{pT}(-) \mathrm{N}(-) \mathrm{M} 1$ \\
\hline 6 & $\begin{array}{c}\text { Takagi et al, } \\
2008^{17}\end{array}$ & $\begin{array}{c}\text { Japan } \\
\text { (Japanese) }\end{array}$ & $50 / \mathrm{M}$ & $\mathrm{Lt}$ & - & Open & Radical & - & - & - \\
\hline 7 & $\begin{array}{c}\text { Makiyama et al, } \\
2012^{10}\end{array}$ & $\begin{array}{l}\text { Japan } \\
\text { (English) }\end{array}$ & $61 / \mathrm{M}$ & Rt & - & Lap & Radical & - & - & pT1aNOM0 \\
\hline 8 & $\begin{array}{c}\text { Rangarajan et al, } \\
2013^{18}\end{array}$ & $\begin{array}{c}\text { India } \\
\text { (English) }\end{array}$ & $65 / \mathrm{M}$ & Rt & $\begin{array}{c}4 \times 3.5 \\
\mathrm{~cm}\end{array}$ & $\begin{array}{l}\text { Non-surgical, } \\
\text { palliative }\end{array}$ & - & - & Clear-cell & $\begin{array}{l}\text { (Clinical } \\
\text { T4N1M1) }\end{array}$ \\
\hline 9 & $\begin{array}{c}\text { Terakawa et al, } \\
2013^{11}\end{array}$ & $\begin{array}{l}\text { Japan } \\
\text { (English) }\end{array}$ & $81 / \mathrm{M}$ & $\mathrm{Lt}$ & - & Lap & Radical & - & Clear-cell & pT1bN0M0 \\
\hline 10 & $\begin{array}{l}\text { Current study, } \\
2016\end{array}$ & $\begin{array}{l}\text { Canada } \\
\text { (English) }\end{array}$ & $65 / \mathrm{M}$ & Lt & $\begin{array}{l}9.1 \times 7.2 \\
\times 10 \mathrm{~cm}\end{array}$ & Open & Radical & 3 & Clear-cell & pT3aNOM0 \\
\hline
\end{tabular}

14. Rendon RA, Kapoor A, Breau R, et al. Surgical management of renal cell carcinoma: Canadian kidney cancer forum consensus. Can Urol Assoc J 2014;8:398-412. https://doi.org/10.5489/cuaj.1894

15. Jimenez Verdejo A, Martinez Torres JL, Palao Yago F, et al. Renal cell carcinoma in patient with situs inversus and kartagener syndrome. Actas Urol Esp 2000;24:169-72. hitps://doi.org/10.1016/S0210$4806(00) 72424-7$

16. Jewell J, Bowa K. Situs inversus with renal neoplasm: A case report. East Cent Afr J Surg 2001;6:95-7.

17. Takagi Y, Narushima M, Shimoji T. A case of renal cell carcinoma with situs inversus totalis. Jpn I Clin Urol 2008;62:315-7.
18. Rangarajan S, Sunil B, Shet AS. Situs inversus and metastatic renal cell carcinoma: A case report. IJCRI 2013;3:1-5.

Correspondence: Dr. Justin Oake, Section of Urology, University of Manitoba, Winnipeg, MB, Canada; b96jdo@gmail.com 